\title{
DEVELOPMENT OF THE HIGH-TEMPERATURE REDOX ELECTRODE AND IMPROVED CORROSION RATE METER \\ Interim Report for Period Ending September 1980
}

M. J. Danielson

0. H. Koski

September 1981

Prepared for the U.S. Department of Energy under Contract DE-AC06-76RLO 1830

Pacific Northwest Laboratory Richland, WA 99352 


\section{DISCLAIMER}

This report was prepared as an account of work sponsored by an agency of the United States Government. Neither the United States Government nor any agency Thereof, nor any of their employees, makes any warranty, express or implied, or assumes any legal liability or responsibility for the accuracy, completeness, or usefulness of any information, apparatus, product, or process disclosed, or represents that its use would not infringe privately owned rights. Reference herein to any specific commercial product, process, or service by trade name, trademark, manufacturer, or otherwise does not necessarily constitute or imply its endorsement, recommendation, or favoring by the United States Government or any agency thereof. The views and opinions of authors expressed herein do not necessarily state or reflect those of the United States Government or any agency thereof. 


\section{DISCLAIMER}

Portions of this document may be illegible in electronic image products. Images are produced from the best available original document. 
The oxidation-reduction (redox) electrode studies at Pacific Northwest Laboratory (PNL) were completed with the examination of the sulfide-sulfate system. This system is extremely reducing, and it was concluded that the redox electrode would still respond to the entry of oxygen even though sulfide is an oxygen getter. The corrosion rate of platinum in oxygenated brine was determined at $250^{\circ} \mathrm{C}$. It was concluded that the mechanism of response to oxygen fits a mixed potential model.

Work began on the improved corrosion rate meter (ICR). A potentiostat and programmer were constructed and successfully tested. Corrosion tests were carried out in $25^{\circ} \mathrm{C}$ brine with and without oxygen, and the ICR response was very good when compared to corrosion rates determined by weight loss. Future work will involve autoclave tests and development of microprocessor control of the electronics to simplify the measurements. 


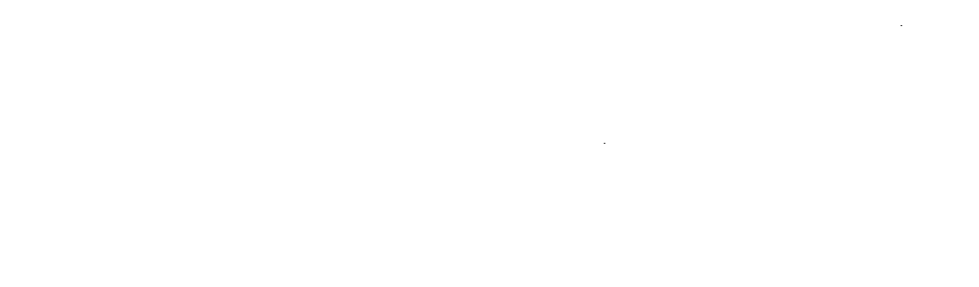


CONTENTS

SUMMARY AND CONCLUSIONS . INTRODUCTION

REDUX ELECTRODE

IMPROVED CORROSION RATE METER . BACKGROUND

PNL-DESIGNED EQUIPMENT

FUTURE WORK

REFERENCES i i

1

3

7

7

9

17

19

A. 1

B. 1

v 


\section{FIGURES}

1 Selected Theoretical and Experimental Redox Potentials on a Pt-Pt Electrode . . . . . . . . . . . .

2 Danielson-Koski Multipoint Programmable Potentiostat Analog Board-1 . . . . . . . . . . . .

3 Danielson-Koski Multipoint Programmable Potentiostat Digital Time Control

4 Corrosion Rate Measurements in a Simulated Geothermal Brine

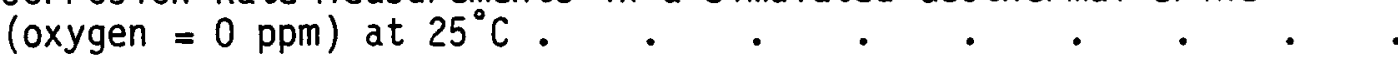

5 Corrosion Rate Measurements in a Simulated Geothermal Brine (oxygen $=4 \mathrm{ppm}$ ) at $25^{\circ} \mathrm{C}$.

B.1 Error in $I_{-}|\triangle E|$ That Results in a $\pm 50 \%$ Error in the Calculated Corrosion Rate When $|\Delta E|=10 \mathrm{mV}$. . . . . . . . . 8.4

B.2 Error in $I_{-}|\Delta E|$ That Results in a $\pm 50 \%$ Error in the Calculated Corrosion Rate When $|\Delta E|=20 \mathrm{mV}$. . . . . . . B.5

B.3 Error in $I-|\Delta E|$ That Results in a $\pm 50 \%$ Error in the Calculated
Corrosion Rate when $|\Delta E|=30 \mathrm{mV}$.

B.3 Error in $I-|\Delta E|$ That Results in a $+50 \%$ Error in the Calculated
Corrosion Rate when $|\Delta E|=30 \mathrm{mV} . .$. 


\section{INTRODUCT ION}

Any system used to control scaling or corrosion in a geothermal power plant must include provisions for monitoring and verifying the fluid chemistry. Current methods (for example, sampling for later analysis) are not entirely satisfactory; a better method would involve inserting in-line or down-hole chemical sensor probes. Using such sensors, continuous on-line data could be produced without the problems associated with sampling, such as infrequency, contamination, or chemistry changes caused by cooling. In-line probes for high-temperature geothermal environments are beyond the current commercial state of the art; however, technological advances have occurred in recent years largely because of the need for such probes in high-pressure nuclear power plants.

The laboratory development of the redox electrode has been completed, and the development of the improved corrosion rate meter (ICR) has begun. In earlier work, (1) it was discovered that the entry of oxygen into geothermal brines results in enhanced corrosion rates and that commercial corrosion rate meters could not recognize these conditions. There were two apparent tasks: to develop the redox electrode to recognize oxygen intrusions and to develop an ICR.

Pacific Northwest Laboratory $(\mathrm{PNL}){ }^{(a)}$ proposed to accomplish both tasks since it was originally thought that the redox electrode could provide insight into solution chemistry as well as oxygen intrusions. An earlier report (2) on the redox electrode indicated that it does not respond to the general redox environment in any $k$ ind of thermodynamic response although it is extremely sensitive to oxygen entry. ICR development was undertaken because it is important to have accurate, on-line corrosion information to warn of any chemistry perturbations that could result in catastrophic corrosion rates. Further, under varying conditions, commercial equipment can both underestimate and overestimate actual corrosion rates. The objective of this work is to develop a more flexible instrument that would respond with correct corrosion rates under a wider range of conditions.

(a) Operated for the U.S. Department of Energy (DOE) by Battelle Memorial Institute. 
The remainder of this report discusses the progress that has been made on the redox electrode and the ICR. Work that is to be done in the future is also described. 


\section{REDOX ELECTRODE}

In previous redox electrode work, ${ }^{(1)}$ the sulfide system was not investigated. However, the redox electrode in a sulfide-sulfate system was examined in the current work for completeness and because sulfides are important components of geothermal brines.

The chemistry used was the same as in earlier work: (1) $2.5 \% \mathrm{NaCl}, 450-\mathrm{ppm}$ $\mathrm{SiO}_{2}, 400-\mathrm{ppm} \mathrm{SO} 4^{2-}, \mathrm{CO}_{2}=1 \mathrm{~atm}$, and $\mathrm{pH}=5.7$ at $25^{\circ} \mathrm{C}$. In one experiment, sodium sulfide was added to make a sulfide concentration of $24 \mathrm{ppm}$. 0xygen was sparged out of the solution before the sulfide was added, the tank was sealed, and a positive pressure of $\mathrm{CO}_{2}$ was maintained to exclude air. The data are shown in Figure 1.

In another experiment, the sulfate was removed and a similar experiment was run with only sulfide (see Figure 1). The presence or absence of sulfate had little to no effect on the redox potential, which implies that there is no redox couple between sulfide and sulfate. The potential regime for the sulfide system is in the strongly reducing region as would be expected. In general, the redox electrode will still respond to oxygen intrusions if free oxygen is present at the electrode surface. Sulfide is an oxygen getter at elevated temperatures; and by mixed potential theory, the potential will be displaced into the anodic region if sulfide and oxygen react at the electrode.

The mechanism of the redox electrode's responses was examined in earlier work. (1) The response to oxygen indicated that the behavior was not thermodynamic. It was hypothesized that the response was a mixed potential response in which platinum (Pt) was slowly corroding. To test this hypothesis, the corrosion rate of $\mathrm{Pt}$ foil was determined by weight loss at $250^{\circ} \mathrm{C}$ in the usual solution with 4.0-ppm oxygen. The weight loss for the three coupons after 13 days was $3.0 \pm 0.4 \times 10^{-5} \mathrm{~g} / \mathrm{cm}^{2}$, which corresponds to a corrosion rate of $4.1 \pm 0.5 \times 10^{-4} \mathrm{~mm} / \mathrm{yr}(0.016 \pm 0.002 \mathrm{mils} / \mathrm{yr})$ or a corrosion current of $2 \times$ $10^{-8} \mathrm{~A} / \mathrm{cm}^{2}$ for $\mathrm{Pt}$ assuming a valence state of four.

In ealier work, (1) attempts were made to measure the exchange current (current at open circuit). Unfortunately, the true steady-state current could 


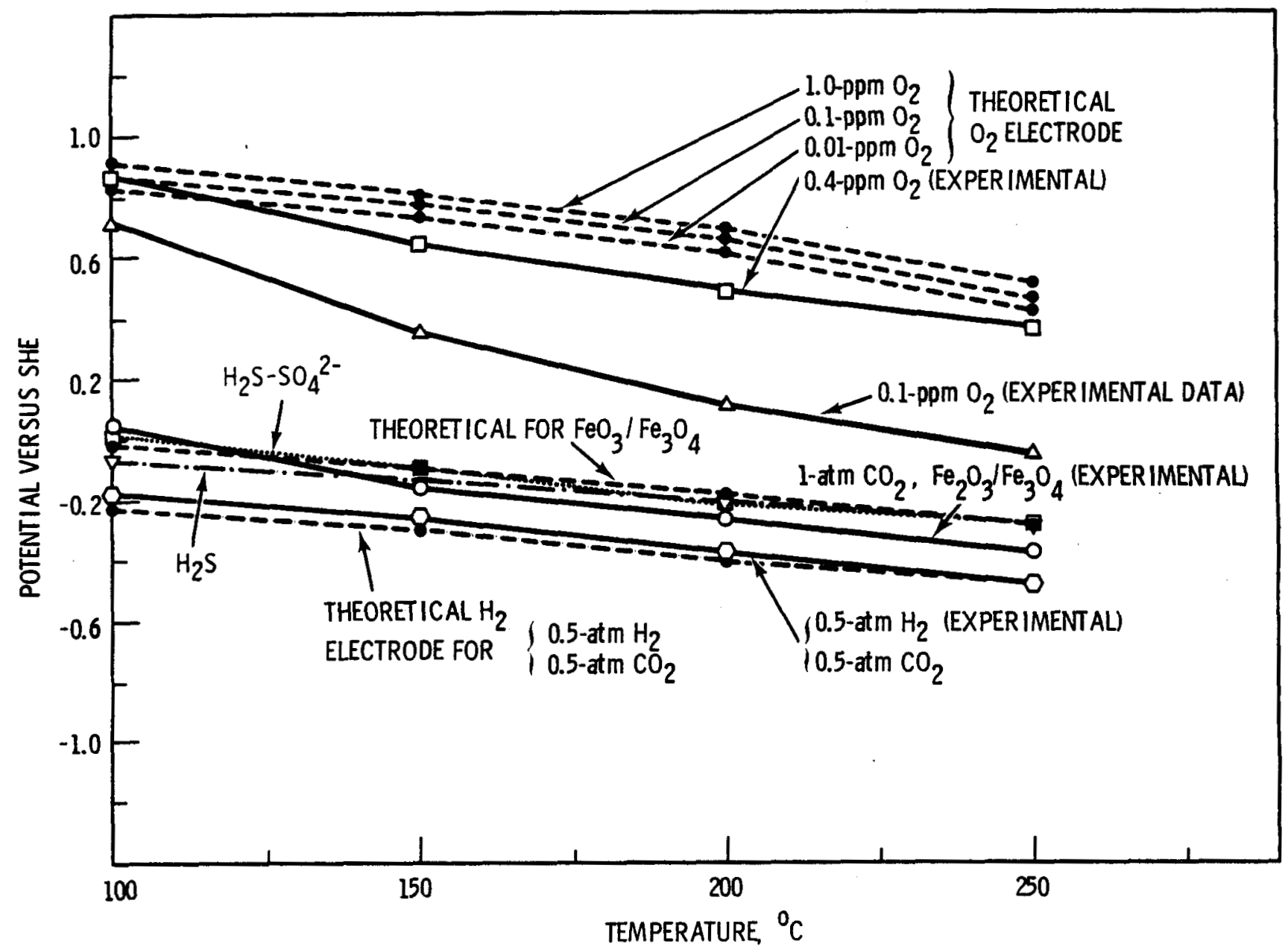

FIGURE 1. Selected Theoretical and Experimental Redox Potentials on a Pt-Pt Electrode

not be obtained from polarization measurements even after 45 min of observation (absolute value of the currents was always decreasing). As a result, all calculated exchange currents were too high. An average $\Delta I / \Delta E$ value, which was calculated from the three polarization data points ( 30 to 45 min before each data point was taken), can be converted into an exchange current by multiplying it by a Tafel slope parameter (estimated to be $20 \mathrm{mV}$ ). Using $\Delta \mathrm{I} / \Delta E=$ $0.022 \mu \mathrm{A} / \mathrm{mV}$ for $\mathrm{Pt}$ foil at $250^{\circ} \mathrm{C}$ and a geometric area of $2.8 \mathrm{~cm}^{2}$, the exchange current equals $1.6 \times 10^{-7} \mathrm{~A} / \mathrm{cm}^{2}$. This calculation considerably overestimated the exchange currents since many hours ${ }^{(3)}$ would be needed to achieve a true steady-state current. The calculated exchange current would 
probably be close to the current measured from weight loss if true steady-state currents were available, which implies that the response of the Pt redox electrode to the environment is due to a mixed potential response with $P t$ corrosion being the anodic reaction. 



\section{IMPROVED CORROSION RATE METER}

In earlier work, (1) commercial equipment that measures corrosion rates was investigated; and it was discovered that commercial equipment is adequate when the brine system is deoxygenated. However, when oxygen is present (the worst case since catastrophic corrosion can result), commercial equipment can significantly underestimate the corrosion rate. The decision was made to develop a corrosion measuring system that would be free of this limitation.

\section{BACKGROUND}

A brief review of how commercial equipment operates and a possible solution to its limitations are outlined in this section. The basic kinetic equation ${ }^{(4)}$ describing many electrochemical processes is:

$$
I=I_{c o r r}\left[\exp \left(\frac{2.3}{b_{a}} E\right)-\exp \left(-\frac{2.3}{b_{c}} E\right)\right]
$$

where

$$
\begin{aligned}
I= & \text { measured current } \\
I_{\text {corr }}= & \text { corrosion current (also called exchange current) } \\
b_{a}, b_{c}= & \text { anodic and cathodic Tafel parameters } \\
E= & E_{\text {applied }}-E_{\text {corr }}=\text { potential perturbation from the open } \\
& \text { circuit corrosion potential. }
\end{aligned}
$$

By taking a partial derivative of Equation (1) with respect to $E$ and then setting it equal to zero at $E=0$, the basic equation under which commercial equipment operates is derived as:

$$
I_{\text {corr }}=\frac{\Delta I}{\Delta E} \cdot B
$$

where $B=\frac{b_{a} \cdot b_{c}}{2.3\left(b_{a}+b_{c}\right)}$. 
$B$ is a constant that is dependent upon the Tafel slope parameters and generally falls between 10 to $45 \mathrm{mV}$ for iron. ${ }^{(5)}$ Some commercial equipment has a $B$ value of about $30 \mathrm{mV}$ hard-wired in place, but a problem arises at elevated temperature when oxygen enters the system and the cathodic reaction (oxygen consumption) becomes mass transport-controlled (independent of potential so that $\left.b_{c} \longrightarrow \infty\right)$. Equation (2) then becomes:

$$
I_{\text {corr }}=\frac{\Delta I}{\Delta E}\left(\frac{b_{a}}{2.3}\right)
$$

If the iron is partially passive, the anodic Tafel value $\left(b_{a}\right)$ can be relatively large (considerably larger than the $30-\mathrm{mV}$ value used in commercial equipment). In earlier work, ${ }^{(1)}$ one case at $150^{\circ} \mathrm{C}$ in oxygenated brine resulted in the actual corrosion rate being six times greater than the rate measured by commercial equipment. Since $B$ is a function of the corroding metal, time of exposure, and chemical environment, the commercial equipment cannot recognize the new conditions when $B$ changes. The ICR will overcome these limitations by determining $a$ B value at the same time the corrosion rate is measured. There are three unknowns in the fundamental kinetic equation $\left(b_{a}, b_{c}\right.$, and $\left.I_{c o r r}\right)$ that require a minimum of three data points for solution of the unknown. Barnartt has investigated this technique and calls it the "three-point method." He found a closed-form solution for Equation (1) when the perturbing potentials have a certain relationship to each other: $|\Delta E|, 2|\Delta E|$, and $-2|\Delta E|$ ( $\triangle E$ is some potential perturbation typically in the range of 5 to $30 \mathrm{mV}$ ). The corrosion rate from Barnartt's (6) work is:

$$
I_{\text {corr }}=\frac{I_{2|\Delta E|}}{r_{2}\left[r_{2}{ }^{2}-4\left(r_{1}\right)^{1 / 2}\right]^{1 / 2}}
$$

$$
\text { where } \begin{aligned}
r_{1} & =\frac{I_{2}|\Delta E|}{I-2|\Delta E|} \\
r_{2} & =\frac{I_{2}|\Delta E|}{I|\Delta E|} .
\end{aligned}
$$


Tafel slope parameters can also be calculated; but the major effect of this method is that the corrosion rate can be calculated even when $B$ values are not constant, which results in a more flexible corrosion rate meter. The potential perturbation pattern is not 1 imited to Barnartt's; several others are shown in Appendix A.

PNL-DESIGNED EQUIPMENT

The PNL-designed potentiostat and programmer board are shown in Figures 2 and 3. The potentiostat maintains a constant potential between the reference electrode and the corrosion specimen (working electrode) and measures the current using a zero current ammeter. The programmer steps the potentiostat through a potential sequence that is set by the operator. The potential increment $(\Delta E)$ is set at the potentiostat; but the programmer steps through the various values of the control potential (such as $-2|\Delta E|,-|\Delta E|,|\Delta E|$, or $2|\Delta E|$ ) and determines the time spent at each potential increment for the current to reach a steady state. Programmer times are steps of $2^{n}$ min when $n$ is permitted to vary from zero to seven in whole numbers. In other words, $1,2,4,8$, etc., minute cycle times are available.

The potentiostat can control the potential between reference and working electrodes within $\pm 0.1 \mathrm{mV}$ for $24 \mathrm{~h}$. The maximum voltage between counter and working electrode was $\pm 10 \mathrm{~V}$ with a maximum current of $10 \mathrm{~mA}$. The speed of the control response was approximately $1 \mathrm{~Hz}$, which is more than adequate for the iron systems studied to date. All inputs to the potentiostat were isolated from earth ground. The potentiostat was designed to be used with the electrodes of a commercial corrosion rate meter (which uses three electrodes of the same material), but there is enough input offset to use other types of reference electrodes. Input impedance between reference and working electrodes was 1 megohm; and three current output ranges were used: 10, 100, and $1000 \mu \mathrm{A} / \mathrm{V}$.

The present model is still in the design stage and is rather complicated to use. The operator must zero the voltage between working and reference electrodes (by adding an input offset voltage), determine the $\Delta E$ increment 

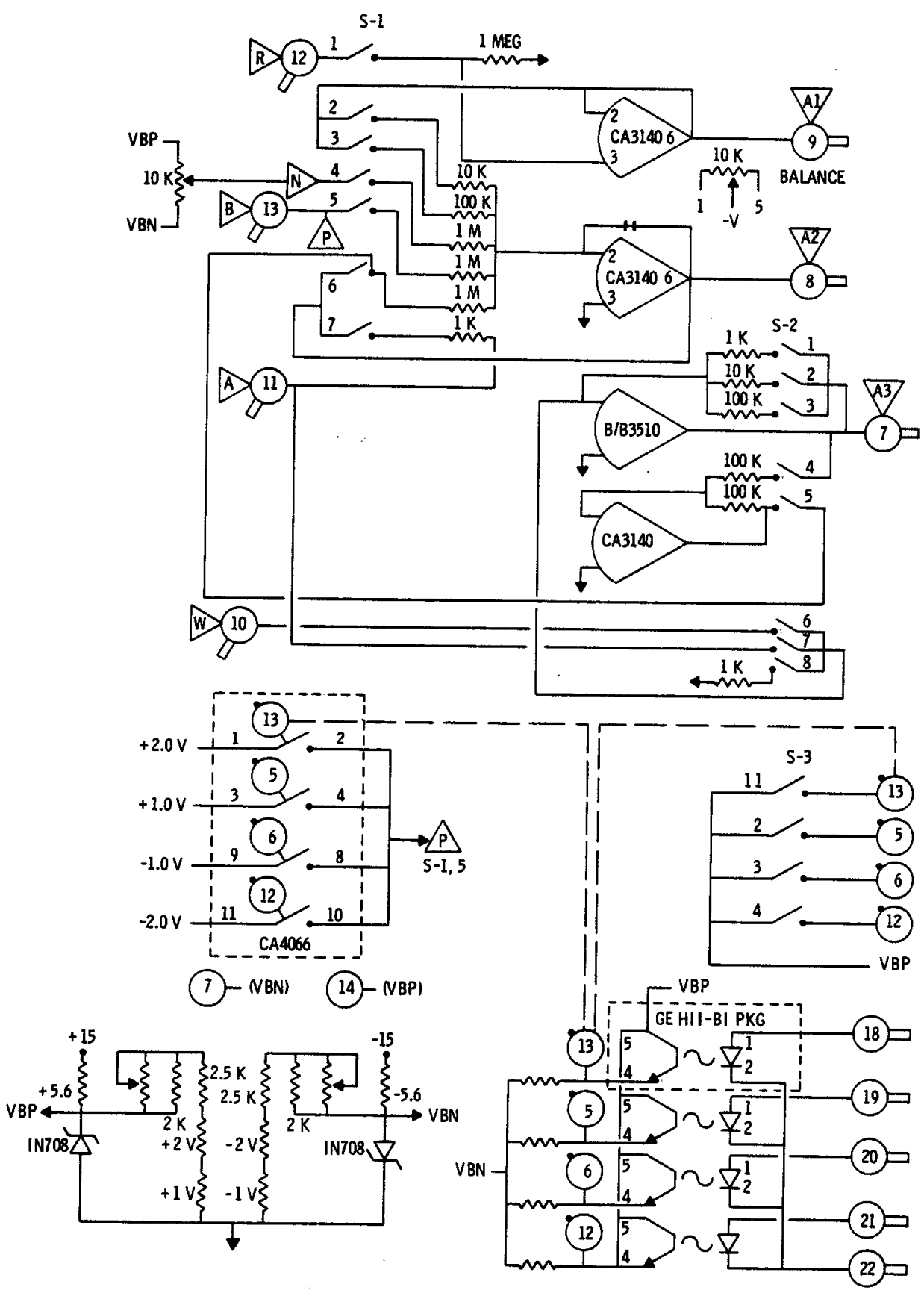

NOTES

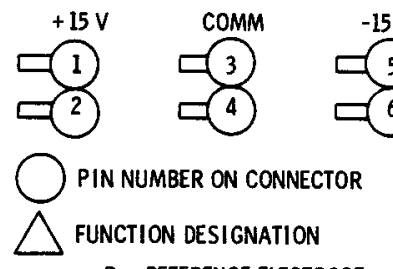

FIGURE 2. Danielson-Koski Multipoint Programmable Potentiostat Analog Board-1

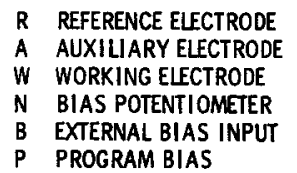




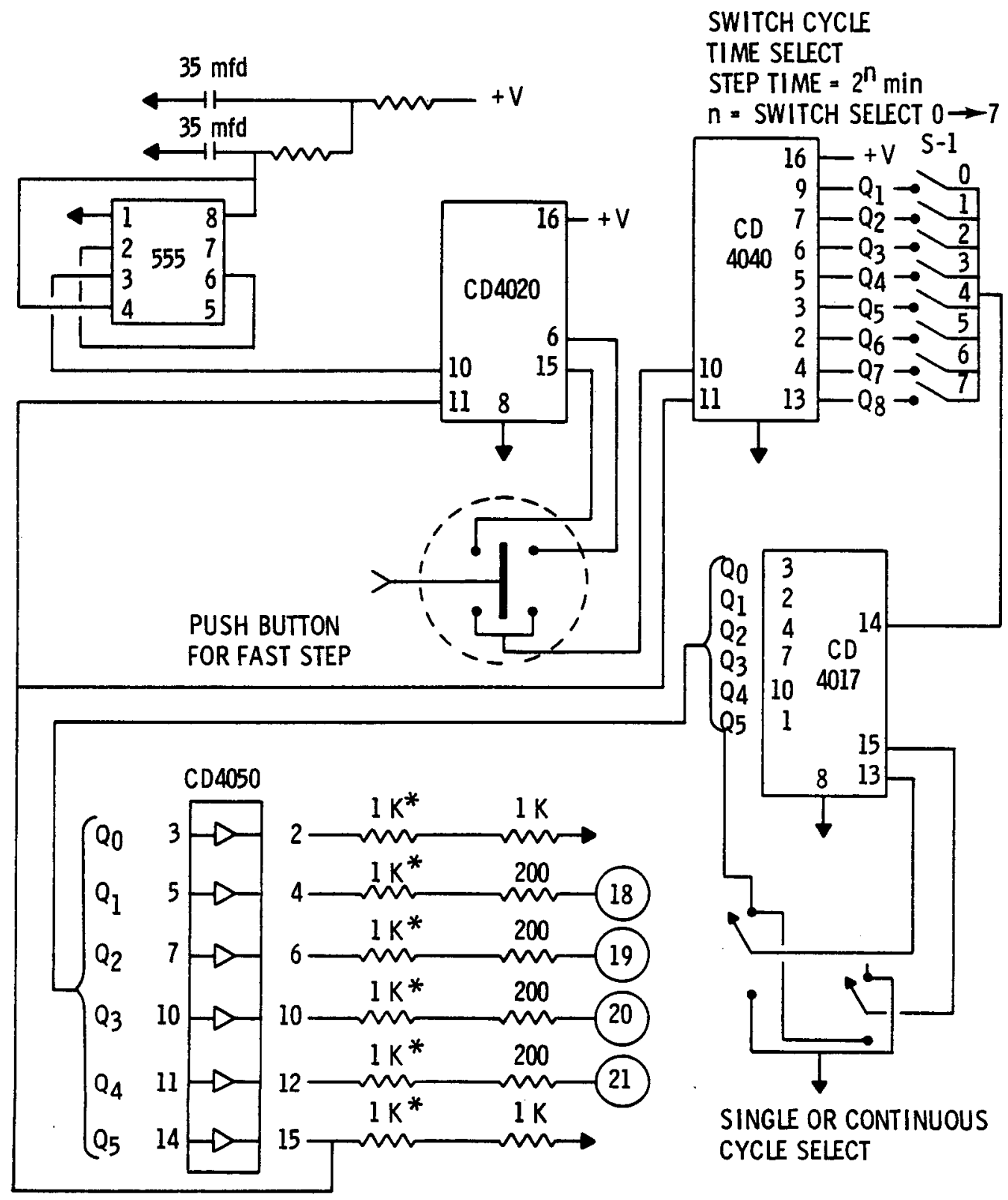

NOTES

(1) $v+$

(3)- (4)

(22) $\mathrm{COMM}$

$\bigcirc$ PIN NUMBER ON CONNECTOR

* EACH NUMBER I K REGI STER SHUNTED BY LED HP5082-4658
FIGURE 3. Danielson-Koski Multipoint Programable Potentiostat Digital

Time Control 
(and the direction of polarization), set the time increment for which each potential will be applied, and then start the programmer cycle. In future editions, microprocessor control will be used to simplify the operation so that field personnel can push one button and read the answer.

The potentiostat and the general three-point procedure were tested in the laboratory. Equipment included a $1-\ell$ polypropylene bottle, a set of mild steel electrodes (1018 steel) for polarization, and three mild steel electrodes to be used as weight loss coupons. Sulfuric acid and brine solutions $(2.5 \% \mathrm{NaCl}$,

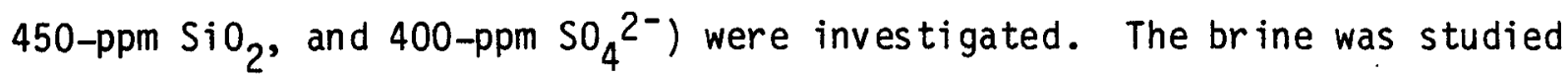
under $1-\mathrm{atm} \mathrm{CO}_{2}$ and under $0.5-\mathrm{atm} \mathrm{CO}_{2} / 0.5-\mathrm{atm}$ air $\left(0_{2}\right.$ in solution $\left.=4 \mathrm{ppm}\right)$. The size of the $\triangle E$ increment and which three polarizations from the group available $(2|\Delta E|,|\Delta E|,-|\Delta E|,-2|\Delta E|$, and $-3|\Delta E|)$ gave the most useful results were also studied.

Initial studies were carried out in $0.047-\mathrm{M} \mathrm{H}_{2} \mathrm{SO}_{4}$ under nitrogen because this system is well characterized. Weight loss measurements gave corrosion rates over $300 \mathrm{mpy}$, and the commercial corrosion rate measuring system also measured around 300 mpy.

There were some problems with applying the three-point method. A potential increment of $10 \mathrm{mV}(|\Delta E|=10 \mathrm{mV})$ was chosen and with most experiments the corrosion current was indeterminate (imaginary solution). Equation (4) indicates that a square root of the difference between two numbers must be taken, and it is possible to take the square root of a negative number if $r_{1}$ or $r_{2}$ is incorrect. All the various forms of the three-point method (see Appendix A) require the square root of the difference between two numbers and can be prone to this problem. However, the three-point method did not work in this case because of the high corrosion rates and the poor geometric relationship of the commercial probes to el iminate IR ${ }^{(a)}$ drop (voltage drop through the solution between the working and reference electrodes). The potentiostat keeps the potential between the working and reference electrodes constant, and the potential drop across the double layer at the working electrode (which drives the electrochemical reaction) as well as the potential drop through the

(a) Current times resistance. 
solution contributes to the potential difference measured between the two electrodes. Generally, the IR drop is negligible and any potential changes are attributed to changes across the double layer; but when the IR drop becomes important, less polarization takes place across the double layer (experimentally, the electrochemical reaction is not driven as hard). It is not always easy to determine the actual polarization across the double layer; and in the case of the three-point method, it was less than required so that the driving potentials were not in the fixed relationship required by this method. There are two extremes when IR drop can be a problem: in solutions of low conductivity when corrosion rates are low and in solutions of high conductivity when corrosion rates are high. The experiment was repeated in $1.0-\mathrm{N} \mathrm{H}_{2} \mathrm{SO}_{4}$ with the reasoning that the improved conductivity would reduce the IR problem; but, unfortunately, the corrosion rate also increased and canceled this effect. The three-point method did not give many real values for the corrosion rate in the 1.0- $\mathrm{N} \mathrm{H}_{2} \mathrm{SO}_{4}$.

In these early experiments, the effect of the size of the potential increment $(\Delta E)$ was examined. It was discovered that when $\Delta E$ became larger $(|\Delta E|=$ $20 \mathrm{mV}$ ), the experimental points were more likely to give a real solution to the corrosion rate. A theoretical analys is of this problem is discussed in Appendix $B$. In general, the larger $\Delta E$ becomes, the farther the measured currents can be from their correct value and still give a real solution. All subsequent work was carried out at $|\Delta E|=20 \mathrm{mV}$. There are two balancing forces at work: the attempt to minimize the error in using the three-point method by employing a large $\Delta E$ and the need to minimize $\Delta E$ to prevent driving the electrode too far away from the freely corroding potential and changing the electrode surface so that later measurements may not accurately represent the way unperturbed portions of the system are reacting.

In the next experiments, the corrosion medium was brine with and without air at $25^{\circ} \mathrm{C}$. These experiments are of interest because the three-point method was shown to be superior to the commercial techniques and because the chemistry is similar to the shutdown conditions of the Magma Electric binary system at East Mesa, California. The experiment using brine and $\mathrm{CO}_{2}\left(\right.$ zero $\mathrm{O}_{2}$ ) is shown in Figure 4 . Weight loss measurements gave a corrosion rate of 16.2 


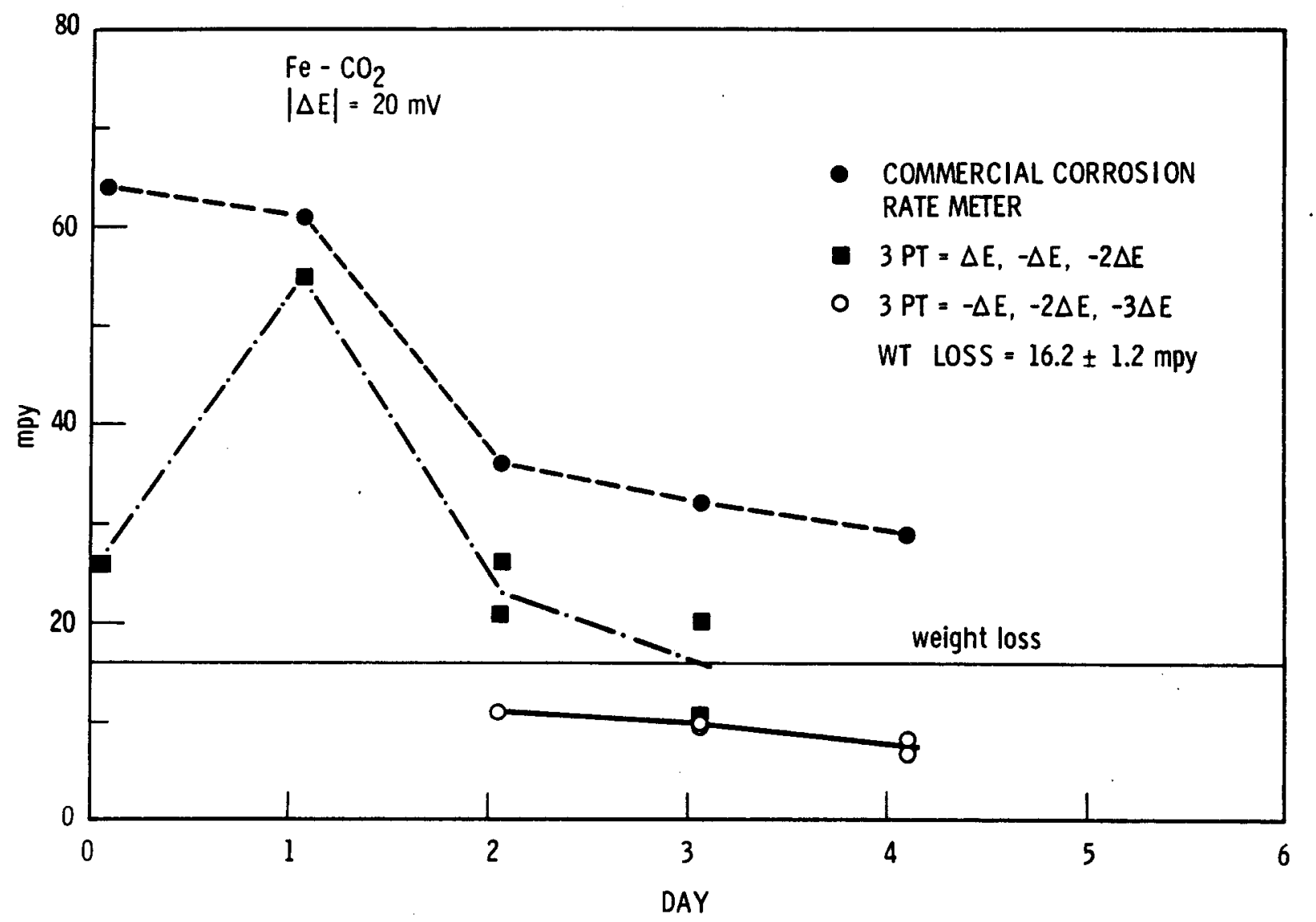

FIGURE 4. Corrosion Rate Measurements in a Simulated Geothermal Brine (oxygen $=0 \mathrm{ppm}$ ) at $25^{\circ} \mathrm{C}$

$\pm 1.2 \mathrm{mpy}$, and integration of rates determined by a commercial corrosion rate meter resulted in a rate of 44 mpy. Several methods were used to evaluate the three-point method using the equations in Appendix A. Calculations using $2|\Delta E|,|\triangle E|$, and $-|\Delta E|$ rarely gave a real solution and are not shown in Figure 4; calculations using $|\Delta E|,-|\Delta E|$, and $-2|\Delta E|$ resulted in an average corrosion rate of $30 \mathrm{mpy}$ and are shown in Figure 4 . Two days after the experiment started, calculations using $-|\Delta E|,-2|\Delta E|$, and $-3|\Delta E|$ were tried; the results were superior since the data almost always gave a real solution. The average corrosion rate for these data was $10 \mathrm{mpy}$, but earlier data would probably have been higher and resulted in an average even closer to that determined by weight loss. 
In the next experiment, brine was used under a $1: 1$ ratio of $\mathrm{CO}_{2}$ : air $\left(0_{2}=4 \mathrm{ppm}\right)$ (see figure 5 ). The average corrosion rate by weight loss was $33+5$ mpy while the average rate from the commercial rate meter was 72 mpy. The three-point method using $2|\triangle E|,|\triangle E|$, and $-|\Delta E|$ is not shown because it never gave a real solution. Calculations based on $|\Delta E|,-|\Delta E|$, and $-2|\Delta E|$ are shown and generally gave either imaginary solutions or extremely large values; no average is reported. Calculations using the all-cathodic data $(-|\Delta E|$, $-2|\Delta E|,-3|\Delta E|)$ were much more successful and gave an average corrosion rate of 28 mpy. In this experiment, duplicate calculations were made; and the three-point method results using all-cathodic data reproduced very wel1. In both brine experiments, the three-point method calculation based on allcathodic data is quite close to the weight loss data and is a marked improvement to the commercial data or other types of three-point method calculations using anodic data.

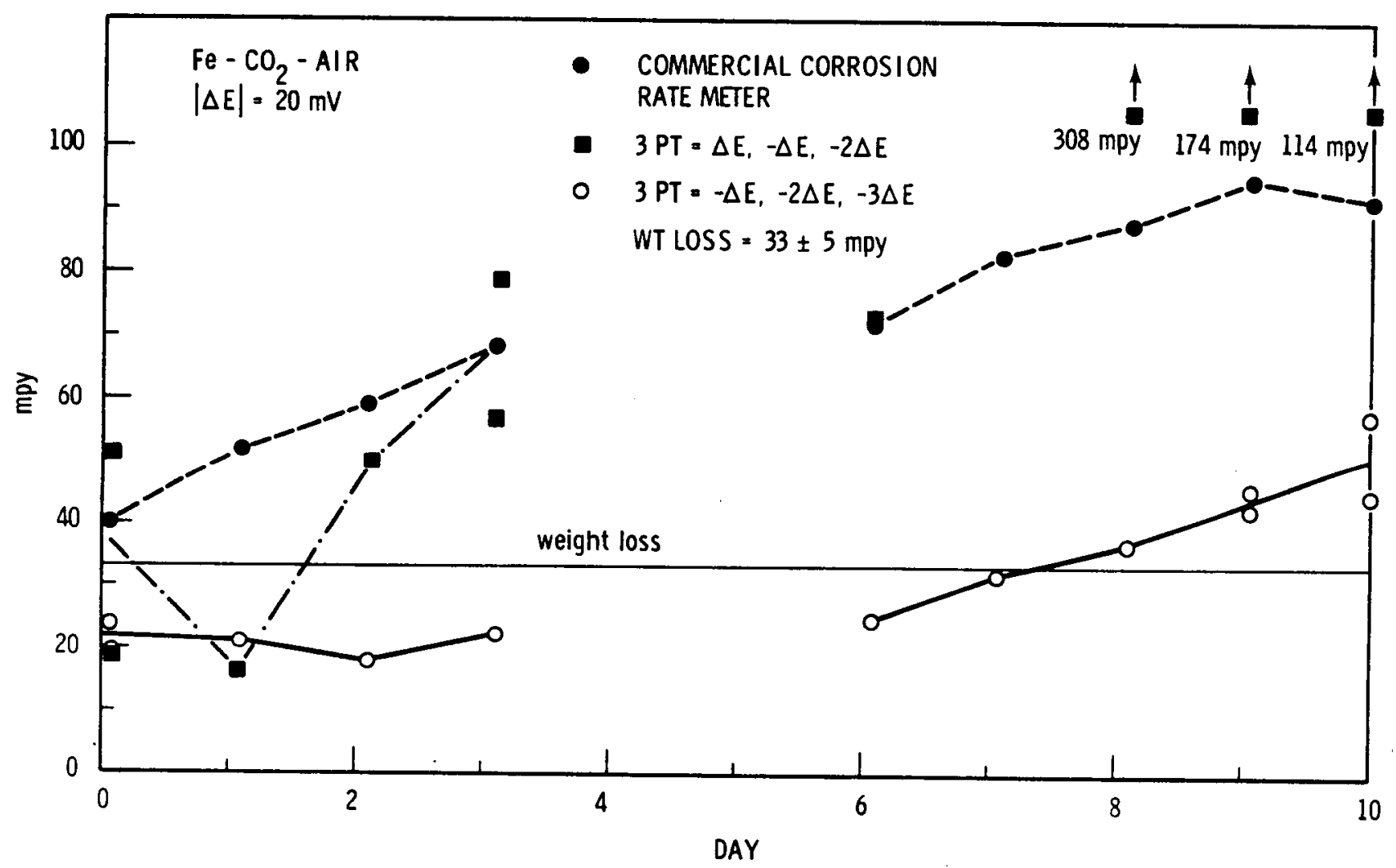

FIGURE 5. Corrosion Rate Measurements in a Simulated Geothermal Brine (oxygen $=4 \mathrm{ppm}$ ) at $25^{\circ} \mathrm{C}$ 
A further problem in using the three-point method is defining steady state for the currents. During anodic polarizations, the current does not reach a steady-state value even after $30 \mathrm{~min}$; however, cathodic values of current reach a steady state within a few minutes. An 8 -min cycle on the programmer was used for these experiments. An investigation of why the anodic data did not permit a real solution indicates that the anodic currents were always less than the correct value (assuming the cathodic currents were correct and agreement with weight loss would make this reasonable). This experimenter does not have an explanation for the anodic behavior of iron, which prevents it from being used for the three-point method.

The corrosion rate nearly doubled (based on weight loss) when oxygen entered the brine system; this is an excellent reason to maintain zero oxygen during shutdown conditions. The commercial corrosion measuring instruments overestimated corrosion rates under these conditions. At elevated temperatures, entry of oxygen will result in even higher corrosion rates and then the commercial instruments will underestimate these high corrosion rates. 


\section{FUTURE WORK}

Future work calls for a field test of the ICR at Magma Electric, East Mesa, California, further laboratory tests in autoclaves, and development of microprocessor control of the ICR. 



\section{REFERENCES}

1. Danielson, M. J. 1980. The Applications of Linear Polarization Techniques to the Measurement of Corrosion Rates in Simulated Geothermal Brines. PNL-3534, Pacific Northwest Laboratory, Richland, Washington.

2. Danielson, M. J. August 1980. Development of the High-Temperature Redox Electrode. PNL-3377, Pacific Northwest Laboratory, Richland, Washington.

3. Prazak, M. 1974. "The Polarization Resistance Method for Corrosion Testing." Werkstoffe and Korrosion 25:104.

4. Vetter, K. 1967. Electrochemical Kinetics. Academic Press, New York.

5. Callow, L. M., J. A. Richardson, and J. L. Dawson. 1976. "Corrosion Monitoring Using Polarization Resistance Measurements." British Corrosion J. 11:123.

6. Barnartt, S. 1970. "Two-Point and Three-Point Methods for the Investigation of Electrode Reaction Mechanisms." Electrochemica Acta. 15:1313. 


\section{APPENDIX A}

THE THREE -POINT METHOD FOR OTHER POTENTIAL SEQUENCES 


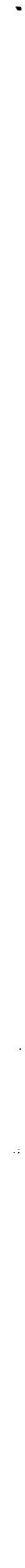


THE THREE-POINT METHOD FOR OTHER POTENTIAL SEQUENCES

Barnartt ${ }^{(6)}$ derived the three-point method for the use of $2|\Delta E|,|\Delta E|$, and $-2|\Delta E|$ potential increments. However, other sequences are possible and several are shown below. A different example from Barnartt's will be derived and the others simply shown.

For the case of $2|\Delta E|,|\Delta E|,-|\Delta E|$ :

$$
\begin{aligned}
\frac{I_{\mid \Delta E} \mid}{I_{\text {corr }}}=\exp \left(\frac{\Delta E}{b_{a}}\right)-\exp \left(\frac{\Delta E}{b_{c}}\right)=u-v \\
\frac{I_{2}|\Delta E|}{I \operatorname{corr}}=\exp \left(\frac{2 \Delta E}{b_{a}}\right)-\exp \left(\frac{-2 \Delta E}{b_{c}}\right)=u^{2}-v^{2} \\
\frac{I_{-}|\Delta E|}{I_{\text {corr }}}=\exp \left(\frac{-\Delta E}{b_{a}}\right)-\exp \left(\frac{\Delta E}{b_{c}}\right)=u^{-1}-v^{-1} \\
r_{1}=\frac{I_{2}|\Delta E|}{I_{\mid \Delta E}}=\frac{u^{2}-v^{2}}{u-v}=u+v \\
r_{2}=\frac{I|\Delta E|}{I_{-}|\Delta E|}=\frac{u-v}{u^{-1}-v^{-1}}=-u v
\end{aligned}
$$

By substituting Equation (A.4) into (A.5) to el iminate $v$ or $u$, the following expressions can be derived:

$$
u=\frac{r_{1}+\left(r_{1}^{2}+4 r_{2}\right)^{1 / 2}}{2}
$$




$$
v=\frac{r_{1}-\left(r_{1}^{2}+4 r_{2}\right)^{1 / 2}}{2}
$$

Substituting Equations (A.6) and (A.7) into (A.1) results in:

$$
\begin{gathered}
I_{\text {corr }}=\frac{I_{(|\Delta E|)}}{\left(r_{1}^{2}+4 r_{2}\right)^{1 / 2}} \\
b_{a}(\text { base } 10)=\frac{2.30(|\Delta E|)}{\ln (u)} \\
b_{c}(\text { base } 10)=\frac{-2.30(|\Delta E|)}{\ln (V)}
\end{gathered}
$$

For the case $|\Delta E|,-|\Delta E|,-2|\Delta E|$ :

$$
\begin{gathered}
I_{\text {corr }}=\frac{I_{|\Delta E|}}{\left[\left(r_{1} r_{2}\right)^{2}+4 r_{1}\right]^{1 / 2}} \\
b_{a}\left(\text { base 10) }=\frac{2.3(|\Delta E|)}{\ln \left(\frac{\left\{r_{1} r_{2}+\left[\left(r_{1} r_{2}\right)^{2}+4 r_{1}\right]^{1 / 2}\right\}}{2}\right)}\right. \\
b_{c}\left(\text { base 10) }=\frac{\ln \left(\frac{\left.-r_{1} r_{2}-\left[\left(r_{1} r_{2}\right)^{2}+4 r_{1}\right]^{1 / 2}\right\}}{2}\right)}{r_{1}=\frac{I_{|\Delta E|}}{I_{\mid-\Delta E} \mid}}\right. \\
r_{2}=\frac{I_{-2}|\Delta E|}{I_{|-\Delta E|}}
\end{gathered}
$$


For $-|\Delta E|,-2|\Delta E|,-3|\Delta E|$ :

$$
\begin{gathered}
I_{\text {corr }}=\frac{-I|\Delta E|}{\left(4 r_{2}-3 r_{1}{ }^{2}\right)^{1 / 2}} \\
b_{a}\left(\text { base 10) }=\frac{-2.30(|\Delta E|)}{\ln \left(\frac{\left[r_{1}-\left(4 r_{2}-3 r_{1}{ }^{2}\right)^{1 / 2}\right]}{2}\right)}\right. \\
b_{c}\left(\text { base 10) }=\frac{2.30(|\Delta E|)}{\ln \left(\frac{\left[r_{1}-\left(4 r_{2}-3 r_{1}{ }^{2}\right)^{1 / 2}\right.}{2}\right)}\right. \\
r_{1}=\frac{I_{-2|\Delta E|}}{I_{-}|\Delta E|} \\
r=\frac{I_{-3|\Delta E|}}{-|\Delta E|}
\end{gathered}
$$




\section{APPENDIX B}

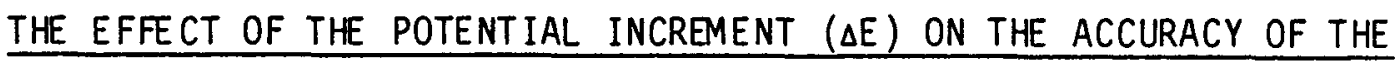
THREE -POINT METHOD 
APPENDIX B

THE EFFECT OF THE POTENTIAL INCREMENT ( $\triangle E$ ) ON THE ACCURACY OF THE THREE -POINT METHOD

This analysis is carried out on calculated currents taken at $|\Delta E|,-|\Delta E|$, and $-2|\Delta E|$. The conclusions will be similar for other potential perturbation combinations, but the exact solution will differ with each system. This error analysis is based on the effect of some inaccuracy in $I_{-}|\Delta E|$ because the current did not reach a correct steady state before the measurement was taken or due to an instrument error in reading the current. $I_{-}|\Delta E|$ was examined because it has the smallest value of the three currents and is most subject to inaccuracies. This analys is will examine how far $I_{-}|\Delta E|$ can vary from the correct value for a $\pm 50 \%$ error in calculating the corrosion rate as a function of $\triangle E$ (over a range of $b_{a}$ and $b_{c}$ values).

Using Equation (B.1), current values for the various polarizations are calculated assuming certain values for $b_{a}$ and $b_{c}$.

$$
I=I_{c o r r}\left[\exp \left(\frac{2.3}{b_{a}} \Delta E\right)-\exp \left(\frac{-2.3}{b_{c}} \Delta E\right)\right]
$$

From Appendix A, the actual corrosion rate is given as:

$$
\left(I_{\text {corr }}\right)_{1}=\frac{I_{|\Delta E|}}{\left[\left(r_{1} r_{2}\right)^{2}+4 r_{1}\right]_{1}^{1 / 2}}
$$

but upon assuming that the value for $\left.I_{-}\right|_{\Delta E} \mid$ is in error $\left(\right.$ called $i_{-}|\Delta E|$ ), a different corrosion rate would be calculated:

$$
\left(I_{\text {corr }}\right)_{2}=\frac{I_{\mid \Delta E} \mid}{\left[\left(r_{1} r_{2}\right)^{2}+4 r_{1}\right]_{2}^{1 / 2}}
$$


For a $50 \%$ overestimation of the actual corrosion rate:

$$
\frac{\left({ }^{\mathrm{I}} \text { corr }\right)_{1}}{\left({ }^{\mathrm{I}} \text { corr }\right)_{2}}=\frac{1}{1.5}=0.667
$$

and for a $50 \%$ underestimation of the actual corrosion rate:

$$
\frac{\left({ }^{I} \text { corr }\right)_{1}}{\left({ }^{I_{\text {corr }}}\right)_{2}}=\frac{1}{0.5}=2.00
$$

The calculation will be demonstrated using Equation (B.4). Making use of Equations (B.2), (B.3), and (B.4):

$$
0.667 A=\left[\left(r_{1} r_{2}\right)^{2}+4 r_{1}\right]_{2}^{1 / 2}
$$

where $A=\left[\left(r_{1} r_{2}\right)^{2}+4 r_{1}\right]_{1}^{1 / 2}$

From Appendix $A$, the expression for the currents is substituted into Equation (B.6):

$$
\begin{aligned}
& r_{1}=\frac{I|\Delta E|}{i-|\Delta E|} \\
& r_{2}=\frac{I-2|\Delta E|}{i-|\Delta E|}
\end{aligned}
$$

and rearranged to give:

$$
\begin{gathered}
i_{-|\Delta E|}^{4}-i_{-|\Delta E|}^{3}\left[\frac{4 I|\Delta E|}{(0.667 A)^{2}}\right]-\frac{\left(I_{|\Delta E|} \cdot I_{-2|\Delta E|}\right)^{2}}{(0.667 A)^{2}}=0 \\
\text { B.2 }
\end{gathered}
$$


Equation (B.9) can be solved numerically; and the $i-|\Delta E|$ can be used in Equation (B.10) to calculate the percent difference from $I_{|-\Delta E|}$, which results in a $\pm 50 \%$ error in corrosion rate.

$$
\frac{i-|\Delta E|-I|-\Delta E|^{\times 100 \%}}{I_{|-\Delta E|}}=\text { percent error in } I_{-}|\Delta E|
$$

These results are shown in Figures B.1, B.2, and B.3, where the measurement error in $I_{-}|\Delta E|$ is explored as a function of $\Delta E$. In general, the larger the $\Delta E$, the greater $\Delta I-|\Delta E|$ can be from the correct value and still be within $\pm 50 \%$. However, good electrochemical practice requires $\Delta E$ to be as small as possible to minimize the effects of each potential perturbation on the next measurement; $\Delta E=20 \mathrm{mV}$ was chosen to be an acceptable compromise. It is not surprising that a large $\Delta E$ gives a more accurate answer. The three-point method depends upon the nonlinear portions of Equation (B.1) to dominate. For small perturbations, the exponentials in Equation (B.1) can be accurately expressed in linear form; and under these conditions the three-point method will fail (in fact, the equation will reduce down to the form used by commercial corrosion rate meters). 


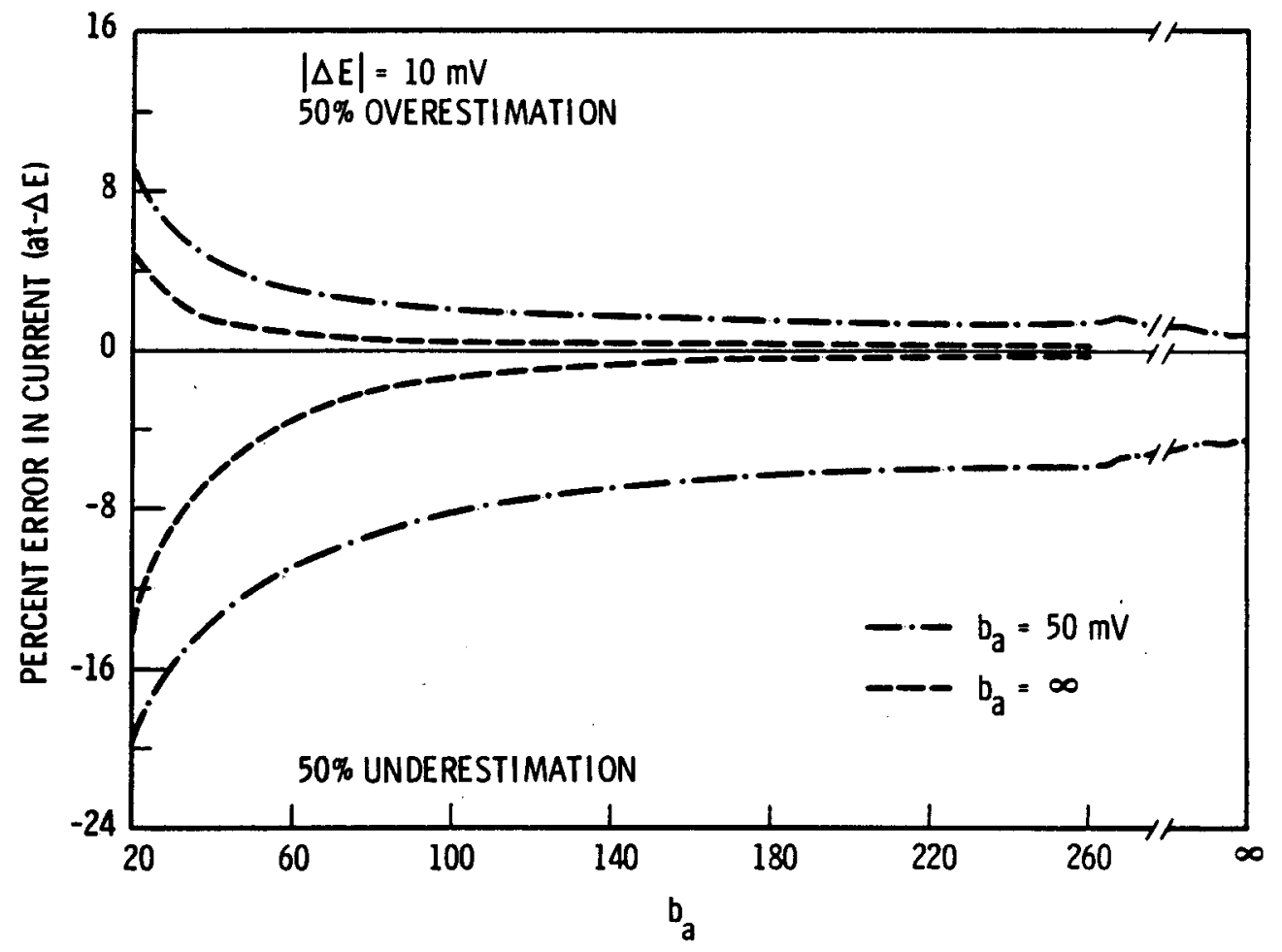

FIGURE B.1. Error in I- $|\Delta E|$ That Results in a $\pm 50 \%$ Error in the Calculated Corrosion Rate When $|\Delta E|=10 \mathrm{mV}$ 


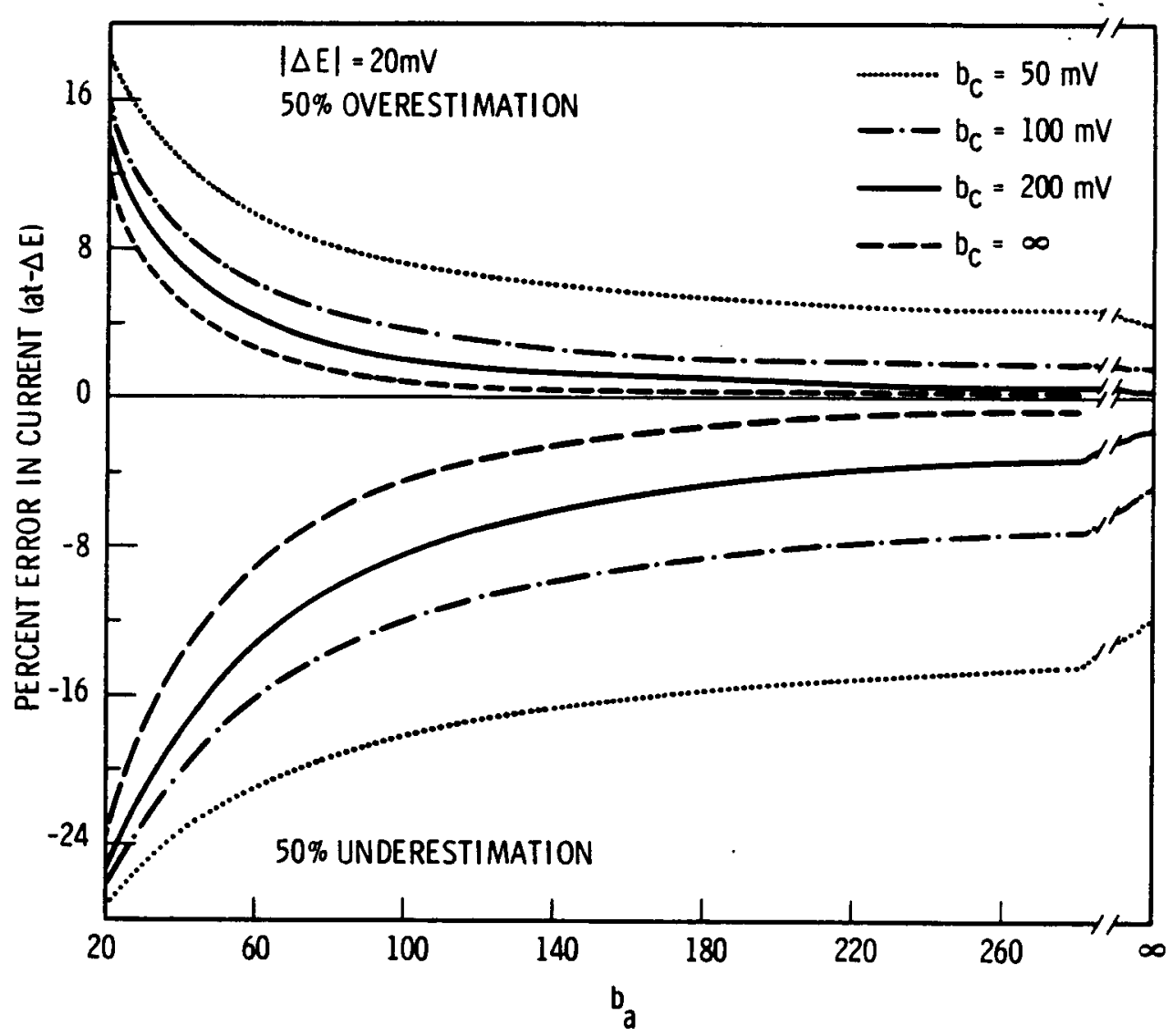

FIGURE B.2. Error in $I_{-}|\Delta E|$ That Results in a $\pm 50 \%$ Error in the Calculated Corrosion Rate When $|\Delta E|=20 \mathrm{mV}$ 


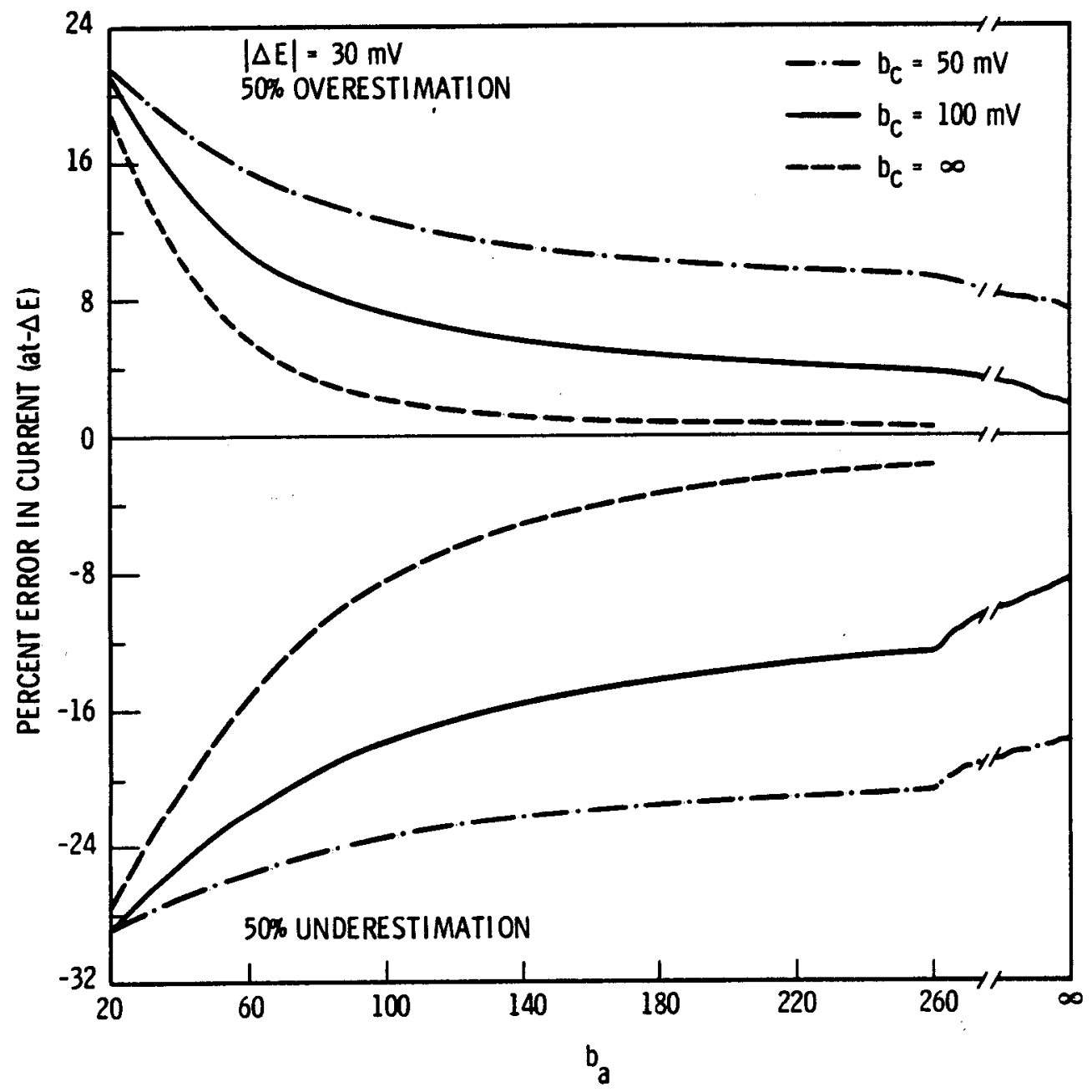

FIGURE B.3. Error in $\left.I_{-}\right|_{\triangle E} \mid$ That Results in a $\pm 50 \%$ Error in the Calculated Corrosion Rate When $|\Delta E|=30 \mathrm{mV}$ 


\section{DISTRIBUTION}

No. of

Copies

OFFSITE

A. A. Churm

DOE Patent Division

9800 S. Cass Avenue

Argonne, IL 60439

2 A. J. Adduci

U.S. Department of Energy

Division of Geothermal Energy

San Francisco Operations Office

1333 Broadway

Oakland, CA 94612

2 R. R. Reeber

U.S. Department of Energy

Division of Geothermal Energy

1200 Pennsylvania Avenue NW

Mail Stop 3344 RA 233

Washington, DC 20461

S. M. Hansen

DOE Energy Technology Systems

Systems and Procedures Section

Mail Station 404, 600 E. Str., N.W.

Washington, DC 20545

27 DOE Technical Information Center

F. Schoepflin

Bechtel Corporation

50 Beale Street

San Francisco, CA 94105

H. E. Englander

Chevron Oil Field Research Co.

P.0. Box 446

La Habra, CA 90631
No. of

Copies

M. G. Reed

Chevron 0il Field Research Co. P.0. Box 446

La Habra, CA 90631

F. W. Schremp

Chevron $0 i l$ Field Research Co. P.0. Box 446

La Habra, CA 90631

W. J. Subcasky

Chevron 0 il Field Research Co. P.0. Box 446

La Habra, CA 90631

R. L. Hall

Geothermal UPD

EG\&G Idaho, Inc.

P.0. Box 1625

Idaho Falls, ID 83401

R. L. Miller

EG\&G Idaho, Inc.

307 Second Street

Idaho Falls, ID 83401

D. Suciv

EG\&G Idaho, Inc.

307 Second Street

Idaho Falls, ID 83401

V. Roberts

Electric Power Research Institute

P.0. Box 10412

Palo Alto, CA 94304

J. Featherstone

2120 South 9 th Street

El Centro, CA 92243 
No. of

Copies

R. A. Reynolds

GHT Laboratories

106 South 8th Street

Brawley, CA 92227

University of Hawai $i$ at Monoa

2424 Maili Way

Honolulu, HI 96822

T. C. Hinrichs

Imperial Magma

P.0. Box 2082

Escondido, CA 92025

C. Grigsby

CNC-2 M.S. 738

Los Alamos Scientific Laboratory

Los Alamos, NM 87545

M. C. Smith

Los Alamos Scient ific Laboratory

P.0. Box 1663

Los Alamos, NM 87544

J. W. Arlidge

Nevada Power Company

P.0. Box 230

Las Vegas, NV 89151

P. N. LaMor $i$

Occidental Research Corporation 2100 S.E. Main Street

P.0. Box 19601

Irvine, CA 92713

R. Potter

Occidental-Research Corporation

P.0. Box 19601

Irvine, CA 92713

R. W. Bowman

Oilwell Research, Inc.

2419 E. Main Street, Suite E

Ventura, CA 93003

P. Lineau

Oregon Institute of Technology

Klamath Falls, OR 97601
No. of

Copies

F. J. Dodd

Pacific Gas \& Electric Co.

3400 Crow Canyon Road

San Ramon, CA 94583

R. McCurdy

Pacific Gas \& Electric

Dept. of Engineering Research

3400 Crow Canyon Road

San Ramon, CA 94583

M. Conover

Radian Corporation

8500 Shoal Creek Road

Austin, TX 78766

J. Barkman

Republic Geothermal, Inc.

11823 E. S1auson Avenue, Suite 1

Santa Fe Springs, CA 90670

C. L. Nealy

Rockwe 11 International

Atomics International Division

8900 DeSoto Avenue

Canoga Park, CA 91304

T. Springer

Rockwe 11 International

Atomics International Division

8900 DeSoto Avenue

Canoga Park, CA 91304

H. K. Bishop

San Diego Gas \& Electric Co.

P.0. Box 1831

San Diego, CA 92112 .

T. Veneruso

Sandia Laboratory

Albuquerque, NM 87185

S. Cramer

U.S. Department of Interior

Bureau of Mines

Avondale Metallurgy Research

Center

Avondale, MD 20782 
No. of

Copies

E. Backstrom

U.S. Department of Interior

Bureau of Reclamation

Engineering and Research

Center,

P.0. Box 25007

Bldg 67, Federal Center

Denver, CO 80225

R. 0. Fournier

U.S. Department of Interior

Office of Geochemistry and

Geophysics

345 Middlefield Road

Men lo Park, CA 94025

I. Barnes

U.S. Geological Survey

345 Middlefield Road

Men lo Park, CA 94025

G. W. Crosby

Phillips Petroleum Company

11526 Sorrento Valley Road

San Diego, CA 92121

L.P.J. Muffler

U.S. Geological Survey

345 Middlefield Road

Men lo Park, CA 94025

J. M. Thompson

U.S. Geological Survey

Geologic Division

Branch of Exp. Geochemistry and Minera logy

345 Middlefield Road

Men 10 Park, CA 94025

A. J. Chasteen

Union 0 il Co. of California

135 Main Street

Brawley, CA 92227

D. Christopherson

Union 0 il Co. of California

P.0. Box 76

Brea, CA 92621
No. of

Copies

W. C. Lieffers

Union 0 il Co. of California

Research Department

P.0. Box 76

Brea, CA 92621

C. Otte

Union $0 i 1$ Co. of California

P.0. Box 7600

Los Angeles, CA 90017

R. N. Wheat ley

Union $0 i l$ Co. of California

Research Department

P.0. Box 76

Brea, CA 92621

J. Farison

Union 0i1-Geothermal

P.0. Box 6854

Santa Rosa, CA 95401

0 . Vetter

Vetter Associates

3189 C Airway Avenue

Costa Mesa, CA 92626

R. C. Sones

Westec Services, Inc.

East Mesa Test Site

P.0. Box 791

Holtville, CA 92250

\section{ONSITE}

DOE Richland Operations Office

H. E. Ransom

54 Pacific Northwest Laboratory

J. Britton

M. J. Danielson (25)

R. L. Dillon (2) 
No. of

Copies

J. R. Divine

J. L. Duce

S. K. Edler

D. H. Getchell

B. Griggs

C. R. Hann

G. A. Jensen

D. Jones
No. of

Copies

C. H. Kindle

0. H. Koski (5)

P. Morrow

L. D. Perrigo

D. W. Shannon

R. P. Smith

R. G. Sullivan

Technical Information (5)

Publishing Coordination Y0(2) 